\title{
Implementation of MOORA Method in Evaluating Work Performance of Honorary Teachers
}

\author{
Sofiansyah Fadli \\ STMIK Lombok, Teknik Informatika \\ Jln. Basuki Rahmat No. 105 Praya, Indonesia \\ sofiansyah182@gmail.com
}

\author{
Khairul Imtihan \\ STMIK Lombok, Teknik Informatika \\ Jln. Basuki Rahmat No. 105 Praya, Indonesia \\ khairulimtihan31@gmail.com
}

\begin{abstract}
Teachers posses an essential role in advancing schools and students. Therefore, the quality of teachers holds a significant aspect since their main tasks are to educate, teach, guide, direct, train, assess and evaluate students. That being said, having professional teachers and teaching staff is compulsory for schools in order to implement quality education processes. For this reason, schools always encourage improvement of teachers' work performance and hence improve the quality of the management system of teaching staff by monitoring teachers' work in implementing their tasks so that they can achieve the predetermined competency standards. Central Lombok Regency is one of the regencies in the Province of West Nusa Tenggara (NTB) with a total of 18 state high schools (SMAN) and a large number of honorary teachers.

This study aims to develop a decision support system to facilitate the process of teacher performance evaluation using the MOORA method. Previously, the evaluation was performed manually based on direct observations by principals wherein they appointed potential teachers based on the evaluation criteria of honorary teacher performance. Such method is considered ineffective since it could cause internal conflicts among teachers and might cause some parties feel disadvantaged. To prevent this from happening, a system that can help in the process of evaluating teacher performance is necessary where the results can be used as references or recommendations for school principals. The first step taken is finding supporting data as mandated by The Minister of National Education Regulation No. 16 of 2007 on Academic Qualification Standards and Teacher Competency Standards. The criteria used in evaluating work performance of teachers are based on pedagogical, personality, social, and professional competence, with sub criteria. The data is then analyzed using (1) the Analytical Hierarchy Process (AHP) method to determine the weight of each competency, and (2) the Multi-Objective Optimization on the Basis of Ratio Analysis (MOORA) method to determine the highest alternative value or the highest performance value of honorary teachers based on a predetermined weight by processing the ranking.

The ranking method is expected to be used as a solution in determining the honorary teacher who has the best performance based on the weight multiplication ranking of each criterion. The implementation of the decision support system using the AHP and MOORA methods can facilitate the process of evaluating the performance of honorary teachers so that the results can be adopted as a reference for school principals in providing recommendations for outstanding teachers who deserve to be promoted.
\end{abstract}

Keywords - AHP, Work Performance Evaluation, MOORA, Decision Support System. 


\section{INTRODUCTION}

Teachers have a significant role in advancing schools and students, which thus deems the quality of teachers a very important aspect. Teachers have the main tasks to educate, teach, guide, direct, assess and evaluate students. For this reason, schools always encourage improvement in teachers' work performance by monitoring the work of teachers in implementing their tasks so that they can achieve the predetermined competency standards. Selection of outstanding teacher aims to increase teachers' motivation in improving their work performance and professionalism. The selection starts from education unit level, Regency/City, Province to National. One of the forms of appreciation given to the winner is an aid in career promotion, and awarding (Haswan, 2015).

However, the process of work performance evaluation of honorary teachers in Central Lombok with 18 state senior high schools (SMAN) and a large number of honorary teachers is still constrained by a number of reasons, some of which are the absence of indicator of work performance of honorary teachers and the unavailability of decision support systems which can facilitate the process of evaluating the performance. According to several school principals in Central Lombok, the performance evaluation of honorary teachers was carried out conventionally (Fadli, 2018). This leads to several consequences; (1) the system used to evaluate it is still manual; (2) the important criteria and sub-criteria in which teachers should pay attention in order to improve their work performance are still undecided; (3) teachers are unaware of which result of performance evaluations is good or less than satisfactory, and (4) there is a subjectivity in the decision making process such as the fact that some honorary teachers have abilities that are not much different from the others. Therefore, teachers'career promotion and awarding become the policy and authority of school principal (Fadli, 2018).

A research conducted by (Fadli \& Winarno, 2017), entitled "Decision Support System for Work Performance Evaluation of High School/Vocational Schools Principles in Central Lombok NTB", aims (1) that decision support systems can be used as a tool to evaluate the work performance of school principals, so that they are expected to be able to help decision makers, and (2) to obtain valid, objective and reliable information about the performance of school principals based on the competency standards of principals in accordance with applicable regulations (Boki, Statiswaty, \& Subardin, 2016). The results are then used to determine the training that will be carried out to improve the quality of the principals' work performance. The criteria used in this study are guided by the work performance evaluation of principals based on the Minister of National Education Regulation No. 35 of 2010 (Permendiknas, 35 Tahun 2010)

The assessed criteria include personality, social, learning leadership, school development, resource management, entrepreneurship, and learning supervision. This research has succeeded in making a decision support system for principal work performance evaluation with the final ranking that can be used as an alternative for related officials to assist and facilitate the decision making process (Fadli \& Winarno, 2017).

If this decision making process is assisted by a computerized decision support system, it is then expected that subjectivity in decision making be minimized (Mufizar, Susanto, \& Nurjayanti, 2015), and that it is able to implement and apply all competency criteria for all honorary teachers. Hence, the results obtained will be able to determine the training that will be done to improve the work performance quality of honorary teachers. From the explanation above, the background of this problem is how the decision support system can be used as a tool to evaluate the work performance of honorary teachers, which is then expected to help decision makers obtain objective information on the performance of honorary teachers based on competency standards of honorary teacher in accordance with applicable regulations (Fadli, 2018). The results obtained from this research are used to determine the training that will be performed to improve the work performance quality of honorary teachers.

\section{LITERATURE REVIEW}

\subsection{Literature Review}

In their research "The Decision Support System for Selection of Exemplary Student Using the MultiObjective Optimization on the Basis of Ratio Analysis (MOORA) Method", explained that the criteria used in the study are: report card grades, class attendance, assignment scores, and achievements. The final result obtained from the study is an application that can help the process of selecting outstanding students since it provides an output ranking of students from the largest to the smallest alternative value (Kusuma, Nasution, Safarti, Hondro, \& Buulolo, 2018).

The use of AHP model in their study builds a decision support system to assess employee performance. The method is also used to build decision support systems of teacher performance evaluation (Kusrini \& Gole, 2007). This system is built by adding more criteria in order to reduce the level of subjectivity and improve the accuracy and precision of teacher performance evaluation results.

Decision making process of lecturer performance evaluation using AHP method, the value 
of consistency ratio is smaller for characteristics with a level of activeness in carrying out the three pillars of higher education (Mufizar, Susanto, \& Nurjayanti, 2015).

\subsection{Decision Support System}

In the book (Turban, Rainer, Kelly, \& Potter, 2006) stated that "Decision Support System (DSS) is a computer-based information system that combines models and data to provide support for decision makers in solving semi structured or interdependent problems with extensive user involvement (Kusumadewi, Hartati, Harjoko, \& Wardoyo, 2006).

\subsection{Work Performance Evaluation}

According to (Armstrong \& Taylor, 2014), performance management schemes in general are prepared using ranking and are then determined after conducting work performance evaluation. The ranking shows the quality of work performance or competence displayed by employees by selecting the level on the scale closest to the evaluator's view on how well the employee performed. Furthermore, (Rivai, 2004) stated that performance evaluation refers to a formal and structured system used to measure and assess things related to work, behavior, and results, including the level of class attendance. Work performance measurement is a component of a strategic system in applying standards because it can measure the effectiveness of improving the quality of processes and institutional accountability (Sallis, 2002).

\subsection{Multi Objective Optimization On The Basic Of Ratio Analysis (MOORA)}

The MOORA method is a multi-objective system that optimizes two or more conflicting attributes simultaneously. This method is applied to solve problems with complex mathematical calculations. The MOORA method was introduced (Brauers \& Zavadskas, 2006). This method was first applied by Braurers in 2004 in a multi-criteria retrieval.

MOORA method is widely applied in fields such as management, building, contracting, road design, and economics. This method has a good level of selectivity in determining an alternative. The approach taken by MOORA is defined as a simultaneous process to optimize two or more conflicting constraints on several obstacles (Brauers \& Zavadskas, 2006).

The MOORA method is flexible and easy to understand and separate the subjective parts of an evaluation process into decision weight criteria with several attributes of decision makers (Saaty, 2008). This method has a good level of selectivity in determining an alternative (Boki, Statiswaty, \& Subardin, 2016), of whether the criterion has benefit or cost

The steps to solve the problem using the MOORA method are shown in the figure below:

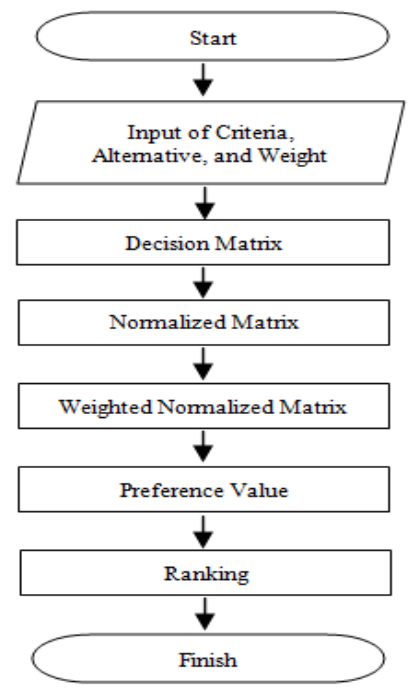

Image1. MOORA Method Flowchart

The steps in solving problem using MOORA method are as follows:

Step 1: Making Decision Matrix

$$
X=\left[\begin{array}{cccc}
X_{11} & X_{12} & \ldots & X m n \\
X_{21} & X_{22} & \ldots & X m n \\
\ldots & \ldots & \ldots & \ldots \\
X n_{1} & X n_{2} & \ldots & X m n
\end{array}\right]
$$

$X$ is the value of each criterion represented as a matrix

Step 2: Normalizing the $\mathrm{x}$ matrix

$$
\mathrm{X}_{\mathrm{ij}}^{*}=\frac{X i j}{\sum_{i=1}^{m} X i j^{2}}
$$

Step 3: Determining the weighted normalized matrix

$$
\mathrm{W}_{\mathrm{j}}^{*} \mathrm{X}_{\mathrm{ij}}
$$

Step 4 : Determining the preference result

$$
\mathrm{Yi}=\sum_{j=1}^{g} w j X * i j-\sum_{j=g+1}^{n} w j X i j
$$

\subsection{Analitycal Hierarchy Process (AHP)}

AHP is a method of approach that is suitable for dealing with complex systems related to the decision making of several alternatives and provide considerable choices. This method was first developed by Saaty (Saaty, 2008), (Kusumadewi, Hartati, Harjoko, \& Wardoyo, 2006). The hierarchical model stated by Saaty is a functional hierarchical model with the main input being human perception. 
Below are several principles that must be understood in resolving problems with AHP:

a. Decomposition

Complex systems can be understood by breaking them down into smaller elements which thus make them easily understood, and then arranging them hierarchically like the following picture:

b. Comparative Judgment

Criteria and alternatives are done by pairwise comparisons. According to (Saaty, 2008), for various problems, scale 1 to 9 is the best scale for expressing opinions. The value and definition of qualitative opinions from the Saaty comparison scale can be measured using an analysis table as follows:

Tabel 1. Paired Comparative Assessment Scale

\begin{tabular}{|c|c|}
\hline $\begin{array}{l}\text { Intensity of } \\
\text { Importance }\end{array}$ & Information \\
\hline 1 & Both elements hold the same importance \\
\hline 3 & $\begin{array}{l}\text { One element is slightly more important than } \\
\text { the other }\end{array}$ \\
\hline 5 & One element is more important than the other \\
\hline 7 & $\begin{array}{l}\text { One element is much more important than the } \\
\text { other }\end{array}$ \\
\hline 9 & $\begin{array}{l}\text { One element is so much more important than } \\
\text { the other element }\end{array}$ \\
\hline $2,4,6,8$ & When in doubt between two close values \\
\hline Inversion & $\begin{array}{l}\text { If activity } i \text { gets one number compared to } \\
\text { activity } j \text {, then } j \text { has the inverse value } \\
\text { compared to } i\end{array}$ \\
\hline
\end{tabular}

\section{c. Synthesis of Priority}

Determining the priority of the criteria elements can be viewed as the elements' weight/contribution towards the goals of decision making. AHP conducts element priority analysis using the pairwise comparison method between two elements so that all the existing elements could be included in it. This priority is determined based on the views of experts and parties interested in decision making, both directly (through discussion) and indirectly (through questionnaire)

\section{d. Logical Consistency}

Consistency has two meanings. First, similar objects can be grouped according to uniformity and relevance. Second, concerning the level of relationship among objects based on certain criteria. In general, the steps in using the AHP method for solving a problem are as follows (Kusumadewi, Hartati, Harjoko, \& Wardoyo, 2006):

1. Defining the problem and determining the desired solution, and then arranging the hierarchy of the encountered problems.
2. Determining the priority of elements

a. The first step in determining the priority of elements is to make a pairwise comparison, i.e. comparing the elements in pairs according to the given criteria.

b. Pairwise comparison matrix is filled using numbers to represent the relative importance of one element towards the other. $\mathrm{K}$ Matrix is a paired comparison matrix between criteria.

3. Synthesis

Considerations of pairwise comparisons are synthesized to obtain the overall priority. The actions done are:

a. Adding up the values of each column in the $\mathrm{K}$ matrix.

b. Dividing each value from the column by the total of concerned column to obtain normalized matrix.

c. Adding up the values of each row and dividing them by the number of elements to get the priority weight value.

4. Measuring Consistency

In making decisions, it is important to understand how good the consistency is because no one wants decisions based on considerations with low consistency (Kusrini \& Gole, 2007). The things done in this step are as follows:

a. Each value in the first column is multiplied by the priority weight of the first element, then each value in the second column is multiplied by the priority weight of the second element and so on.

b. Adding up each row ( $\sum$ row).

c. The sum result of the rows is divided by the concerned priority elements so that it gets lambda.

$$
\lambda=\frac{\sum \text { row }}{\text { priority }}
$$

d. Adding up lambda $(\lambda)$ and dividing the results by the number of the existing elements. The result is called $\lambda$ max.

$$
\lambda_{\max }=\frac{\sum \lambda}{n}
$$

e. where $\mathrm{n}=$ the number of elements compared.

5. Counting the Consistency Index (CI) using formula:

$$
C I=\frac{(\lambda \max -n)}{n-1}
$$

Where $\mathrm{n}=$ the number of elements compared

6. Counting the Consistency Ratio (CR) using formula:

$$
C R=\mathrm{CI} / \mathrm{RC}
$$

where

$\mathrm{CR}=$ Consistency Ratio

$\mathrm{CI}=$ Consistency Index 
$\mathrm{RC}=$ Random Consistency

$\mathrm{RC}$ value has been determined based on the formed comparison matrix and can be presented in the following table

Tabel 2.Random Consistensy (RC) Value

\begin{tabular}{|c|c|c|c|c|c|c|c|}
\hline $\mathrm{N}$ & 1.2 & 3 & 4 & 5 & 6 & 7 & $\ldots$ \\
\hline $\mathrm{Ri}_{\mathrm{n}}$ & 0.00 & 0.58 & 0.90 & 1.12 & 1.24 & 1.32 & $\ldots$ \\
\hline
\end{tabular}

7. Checking the hierarchy consistency

If the value is more than $10 \%$, then the judgment data must be corrected. However, if the Consistency Ratio $(\mathrm{CI} / \mathrm{RC})$ is less than or equal to 0.1 , then the calculation results can be declared correct (Kusrini, 2007).

\section{RESEARCH METHOD}

\subsection{Design Model}

Research on the application ofMulti-Objective Optimization On The Basis of Ratio Analysis (MOORA) method in evaluating work performance of honorary teachers which will be combined with AHP method, will use prototyping method in the design model (Fadli, 2018). The activities in the design model are as follows:

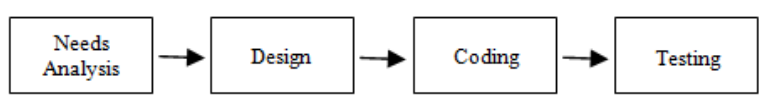

Image 3. Sequential Linear Model (Pressman, 2005)

a. Needs analysis is a stage of analyzing the things needed in making software.

b. The design stage is the translation stage from the analyzed data into a form that is easily understood by the user.

c. Coding is the data translation stage that has been designed using a specific programming language.

d. Testing is a testing stage of the software that has been made.

\subsection{Data Collection Method}

a. Observation: Data collection is based on direct observations at the research location.

b. Interview: Data was collected in the form communication with related parties.

c. Documentation: Data was collected in the form of images and files related to research.

\subsection{Stages of the Research}

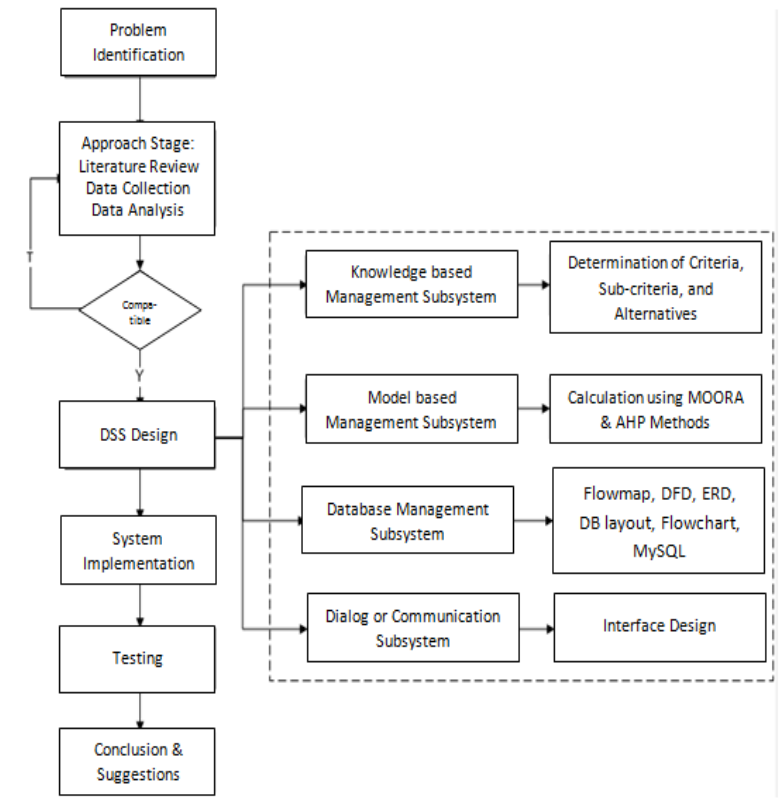

Image 3.2 Research Stages

The implementation of this system is carried out using two process methods; weighting using the AHP method and ranking using MOORA method. In the AHP method, after the weight is obtained, it will proceed with testing for consistency to reveal whether the weight is consistent or not. If the weight is consistent, it will produce a weighting; and if not it will return to the pairwise comparison matrix. After weighting is obtained, it will proceed with ranking using the MOORA method. The weight obtained in the AHP method will go into the weighted normalized matrix.

1. Criteria

In a research to determine outstanding teacher as a career promotional event, the criteria used include

Table 3. Outstanding Teacher Criteria

\begin{tabular}{|l|l|l|}
\hline No & Criteria & Information \\
\hline 1 & C1 & Special achievement \\
\hline 2 & C2 & Leadership trait \\
\hline 3 & C3 & Activeness in school \\
\hline 4 & C4 & Attendance \\
\hline 5 & C5 & Extracurricular activity \\
\hline 6 & C6 & Peer relationship \\
\hline
\end{tabular}

2. Alternatives

Data used to evaluate work performance of honorary teachers:

Table 4. Outstanding Teacher Criteria

\begin{tabular}{|l|l|l|}
\hline No & Alternatives & Information \\
\hline 1 & A1 & Erwin Nopramana, S.Pd \\
2 & A2 & Baehaki, S.Pd \\
\hline
\end{tabular}




\begin{tabular}{|l|l|l|}
3 & A3 & Siti Zahrah, S.Pd \\
4 & A4 & Dara Pusfita, S.Pd \\
5 & A5 & L. Riadusshalihin, S.Pd \\
\hline
\end{tabular}

IV. RESUlt AND ANALYSIS

Calculation Analysis Using AHP Method

Determining the priority of elements by compiling these criteria in the form of a pairwise comparison matrix.

Table 5. Pairwise Comparison Matrix

\begin{tabular}{|c|c|c|c|c|c|c|}
\hline Criteria & C1 & C2 & C3 & C4 & C5 & C6 \\
\hline $\mathrm{C} 1$ & 1 & 2 & 3 & 3 & 2 & 2 \\
\hline $\mathrm{C} 2$ & $1 / 2$ & 1 & 2 & 2 & 3 & $1 / 3$ \\
\hline $\mathrm{C} 3$ & $1 / 3$ & $1 / 2$ & 1 & $1 / 2$ & 2 & $1 / 3$ \\
\hline $\mathrm{C} 4$ & $1 / 3$ & $1 / 2$ & 2 & 1 & 2 & 2 \\
\hline $\mathrm{C} 5$ & $1 / 2$ & $1 / 3$ & $1 / 2$ & $1 / 2$ & 1 & $1 / 2$ \\
\hline $\mathrm{C} 6$ & $1 / 2$ & 3 & 3 & $1 / 2$ & 2 & 1 \\
\hline
\end{tabular}

The next step is calculating the element value of 'criteria' column, where each element of the criteria column is divided by the number of matrices of each column in table 6 , then adding up value of row matrix in each element

Table6. Normalized Matrix of the Element Value for 'Criteria'

\begin{tabular}{|c|c|c|c|c|c|c|c|}
\hline Criteria & C1 & C2 & C3 & C4 & C5 & C6 & Total \\
\hline C1 & 0,136 & 0,273 & 0,261 & 0,400 & 0,167 & 0,324 & 1,741 \\
\hline C2 & 0,158 & 0,136 & 0,174 & 0,267 & 0,25 & 0,054 & 1,039 \\
\hline C3 & 0,105 & 0,068 & 0,087 & 0,067 & 0,167 & 0,054 & 0,548 \\
\hline C4 & 0,105 & 0,068 & 0,174 & 0,133 & 0,167 & 0,324 & 0,971 \\
\hline C5 & 0,158 & 0,045 & 0,043 & 0,067 & 0,083 & 0,082 & 0,478 \\
\hline C6 & 0,158 & 0,409 & 0,261 & 0.067 & 0,167 & 0,162 & 1,223 \\
\hline
\end{tabular}

After determining the total of columns'criteria', the next step is to calculate the priority value of the criteria or create a matrix for consistency criteria by dividing the total number of elements 'criteria' by the number of criteria. In this case there are 6 criteria namely:

Table 7. Matrix for 'Average Normalized Consistency Criteria'

\begin{tabular}{|c|c|c|c|c|c|c|c|c|}
\hline $\begin{array}{c}\text { Crite } \\
\text { ria }\end{array}$ & $\mathrm{C} 1$ & $\mathrm{C} 2$ & $\mathrm{C} 3$ & $\mathrm{C} 4$ & $\mathrm{C} 5$ & $\mathrm{C} 6$ & Total & $\begin{array}{c}\text { Priori } \\
\text { ty }\end{array}$ \\
\hline C1 & 0,136 & 0,273 & 0,261 & 0,400 & 0,167 & 0,324 & 1,741 & 0,290 \\
\hline $\mathrm{C} 2$ & 0,158 & 0,136 & 0,174 & 0,267 & 0,25 & 0,054 & 1,039 & 0,173 \\
\hline C3 & 0,105 & 0,068 & 0,087 & 0,067 & 0,167 & 0,054 & 0,548 & 0,091 \\
\hline C4 & 0,105 & 0,068 & 0,174 & 0,133 & 0,167 & 0,324 & 0,971 & 0,162 \\
\hline C5 & 0,158 & 0,045 & 0,043 & 0,067 & 0,083 & 0,082 & 0,478 & 0,080 \\
\hline C6 & 0,158 & 0,409 & 0,261 & 0.067 & 0,167 & 0,162 & 1,223 & 0,204 \\
\hline
\end{tabular}

The next step is to multiply the elements in the pairwise comparison matrix column by the priority value in table 7 , where the multiplication results are then added per each row.

Table8. 'Sum of each row' Matrix

\begin{tabular}{|c|c|c|c|c|c|c|c|}
\hline & C1 & C2 & C3 & C4 & C5 & C6 & $\begin{array}{c}\text { Total per } \\
\text { row }\end{array}$ \\
\hline C1 & 0,290 & 0,346 & 0,273 & 0,486 & 0,160 & 0,408 & 1,963 \\
\hline C2 & 0,145 & 0,173 & 0,182 & 0,324 & 0,240 & 0,068 & 1,132 \\
\hline C3 & 0,097 & 0,087 & 0,091 & 0,081 & 0,160 & 0,068 & 0,583 \\
\hline C4 & 0.097 & 0,087 & 0,182 & 0,162 & 0,160 & 0,408 & 1,095 \\
\hline C5 & 0,145 & 0,058 & 0,046 & 0,081 & 0,080 & 0,102 & 0,511 \\
\hline C6 & 0,145 & 0,519 & 0,273 & 0,081 & 0,160 & 0,204 & 1,382 \\
\hline
\end{tabular}

The next stepis to add up the matrix of totalper each row in table 8and the results of the priority values in table 9 .

Table9. Addition of the 'totalper row' elements and the priority value

\begin{tabular}{|c|c|c|c|}
\hline & $\begin{array}{c}\text { Total per } \\
\text { row }\end{array}$ & Priority & Result \\
\hline C1 & 1,936 & 0,290 & 2,253 \\
\hline C2 & 1,132 & 0,173 & 1,305 \\
\hline C3 & 0,583 & 0,091 & 0,674 \\
\hline C4 & 1,095 & 0,162 & 1,257 \\
\hline C5 & 0,511 & 0,080 & 0,591 \\
\hline C6 & 1,382 & 0,204 & 1,586 \\
\hline
\end{tabular}

From table 10, the following values are obtained: $\mathrm{t}=(1 / 6) *((1,936 / 0,209)+(1,132 / 0,173)+$ $(0,583 / 0,091)+(1,095 / 0,162)+(0,511 / 0,080)+$ $(1,382 / 0,204)=6,607$

where $\mathrm{n}=6$, it isobtainedthat $\mathrm{RI}_{6}=1,24$, therefore: $\mathrm{CI}=(6,607-6) /(6-1)=0,1214$

$\mathrm{RI}_{6}=1,24$

$\mathrm{CR}=\mathrm{CI} / \mathrm{RI}_{6}=0,121 / 1,24=0,098$

Since $C R \leq 0,1(0,098 \leq 0,1)$ thenthe consistency ratio from the calculation can be accepted (consistent)

\section{Calculation Analysis Using MOORA Method}

After the weight search is done, the next step is to calculate the MOORA to obtain the ranking of outstanding teacher so that it is clear which one performs the best and which one has the worst performance. The evaluation scale will be taken into account in the evaluation process. This is intended to determine the most outstanding teacher.

Table 11. Evaluation Scale

\begin{tabular}{|cl|cc|}
\hline Codes & Types of Criteria & Information & Value \\
C1 & Special Achievement & Yes & 1 \\
& & No & 0 \\
C2 & Leadership Trait & Yes & 1 \\
C3 & Activeness in school & No & 0 \\
& Very Active & 4 \\
\hline
\end{tabular}




\begin{tabular}{|cl|cl|}
\hline & & Active Enough & 3 \\
& & Less Active & 2 \\
C4 & Attendance & Not active & 1 \\
& & Very diligent & 4 \\
Ciligent enough & 3 \\
C5 & Extracurricular & Less diligent & 2 \\
& activities & Not diligent & 1 \\
& & Yes & 1 \\
& & No & 0 \\
C6 & Peer Relationship & Very good & 4 \\
& & Good enough & 3 \\
& & Poor & 2 \\
& & Not good & 1 \\
\hline
\end{tabular}

The next step is making decision matrix from the result of evaluation scale based on the existing condition.

Table 12. Making Decision Matrix

\begin{tabular}{|c|c|c|c|c|c|c|}
\hline & C1 & C2 & C3 & C4 & C5 & C6 \\
\hline A1 & 1 & 1 & 3 & 4 & 1 & 4 \\
\hline A2 & 1 & 1 & 4 & 3 & 1 & 3 \\
\hline A3 & 1 & 1 & 4 & 4 & 1 & 4 \\
\hline A4 & 1 & 1 & 3 & 3 & 0 & 3 \\
\hline A5 & 1 & 1 & 3 & 3 & 1 & 4 \\
\hline
\end{tabular}

After determining the decision matrix, the next step is to normalize the matrix. The elements in the first column are divided by the root from the sum of the square in the first column, and the element in the second column is divided by root from the sum of the square in the second column, and so on.

Table 13. Normalized Matrix

\begin{tabular}{|c|c|c|c|c|c|c|}
\hline & C1 & C2 & C3 & C4 & C5 & C6 \\
\hline A1 & 0.447 & 0,447 & 0,391 & 0,521 & 0,500 & 0,492 \\
\hline A2 & 0,447 & 0,447 & 0,521 & 0,391 & 0,500 & 0,369 \\
\hline A3 & 0,447 & 0,447 & 0,521 & 0.521 & 0,500 & 0.492 \\
\hline A4 & 0,447 & 0,447 & 0,391 & 0,391 & 0,000 & 0.369 \\
\hline A5 & 0,447 & 0,447 & 0,391 & 0,391 & 0,500 & 0,492 \\
\hline
\end{tabular}

The next step is normalizing weighted matrix. It is done by multiplying the weighted criteria obtained using AHP with Normalized Matrix.

Table 14. Weighted Normalized Matrix

\begin{tabular}{|c|c|c|c|c|c|c|}
\hline & C1 & C2 & C3 & C4 & C5 & C6 \\
\hline Weight & 0,290 & 0,173 & 0,091 & 0,162 & 0,080 & 0,204 \\
\hline A1 & 0,130 & 0,077 & 0,036 & 0,084 & 0,040 & 0,100 \\
\hline A2 & 0,130 & 0,077 & 0,047 & 0,063 & 0,040 & 0,075 \\
\hline A3 & 0,130 & 0,077 & 0,047 & 0,084 & 0,040 & 0,100 \\
\hline A4 & 0,130 & 0,077 & 0,036 & 0,063 & 0,000 & 0,075 \\
\hline A5 & 0,130 & 0,077 & 0,036 & 0,063 & 0,040 & 0,100 \\
\hline
\end{tabular}

The next step is calculating preference value. The benefit attribute will be added to the other benefit attributes, and the cost attribute will be added to the other cost attributes. The yi value is obtained by subtracting the sum of the benefits and costs.

Table 15. Preference Result

\begin{tabular}{|c|c|c|c|}
\hline Alternatives & $\begin{array}{c}\text { Max } \\
(\mathrm{C} 1+\mathrm{C} 2+\mathrm{C} 5+\mathrm{C} 6)\end{array}$ & $\begin{array}{c}\text { Min } \\
(\mathrm{C} 3+\mathrm{C} 4)\end{array}$ & $\begin{array}{c}\text { Value } \\
(\mathbf{y i})\end{array}$ \\
\hline $\mathrm{A} 1$ & 0,347 & 0,120 & $\mathbf{0 , 2 2 7}$ \\
\hline $\mathrm{A} 2$ & 0,322 & 0,110 & $\mathbf{0 , 2 1 2}$ \\
\hline A3 & 0,347 & 0,131 & $\mathbf{0 , 2 1 6}$ \\
\hline A4 & 0,282 & 0,099 & $\mathbf{0 , 1 8 3}$ \\
\hline A5 & 0,347 & 0,099 & $\mathbf{0 , 2 4 8}$ \\
\hline
\end{tabular}

The final step is determining the ranking. The ranking is seen from the value of yi obtained. The teacher who has the highest value of yi is the best alternative to become an outstanding teacher.

Table 16. Ranking

\begin{tabular}{|l|c|c|}
\hline \multicolumn{1}{|c|}{ Alternatives } & Rank & Information \\
\hline L. Riadusshalihin, S.Pd & 1 & Worthy of a career promotion \\
\hline Erwin Nopramana, S.Pd & 2 & - \\
\hline Siti Zahrah, S.Pd & 3 & - \\
\hline Baehaki, S.Pd & 4 & - \\
\hline Dara Pusfita, S.Pd & 5 & - \\
\hline
\end{tabular}

\section{CONCLUSION}

Based on the research conducted by the author on the decision support system for work performance evaluations on honorary teachers using the AHP and MOORA methods, it can be concluded that:

1. Application of this decision support system can simplify the process of selecting outstanding teachers.

2. By implementing this application, school principals can perform a faster, more precise and more accurate evaluation for the selection of outstanding teacher.

3. The application of the decision support system to evaluate the work performance of honorary teachers using the Analytical Hierarchy Process (AHP) and Multi Objective Optimization On The Basis Of Ratio Analysis (MOORA) methods can be implemented and it can also produce the same calculations between manual calculations and systemic calculations, where A5 (Tati Sunarti) with the highest score was chosen as an outstanding teacher and deserved to be given a promotion.

\section{REFERENCES}

Armstrong, M., \& Taylor, S. (2014). rmstrong's handbook of human resource management practice. Kogan.

Boki, R., Statiswaty, \& Subardin. (2016). Sistem pendukung keputusan penentuan calon guru berprestasi menggunakan metode fuzzy tsukamoto "studi kasus: smp negeri 5 kendari”. semanTIK, 93-102. 
Brauers, W., \& Zavadskas, E. (2006). The MOORA method and its application to privatization in a transition economy. Control Cybern.

Fadli, S. (2018). Sistem Pendukung Keputusan Evaluasi Kinerja Guru Honorer SMA Menggunakan Metode Penyelesaian MADM. Seminar Nasional Inovasi Teknologi (pp. 321327). Kediri: UN PGRI Kediri.

Fadli, S., \& Winarno, W. W. (n.d.).

Fadli, S., \& Winarno, W. W. (2017). Sistem Pendukung Keputusan Evaluasi Kinerja Kepala Sekolah Sma/Smk Kabupaten Lombok Tengah Ntb. Prosiding Seminar Nasional Inovasi Teknologi (pp. 299-308). Kediri: UN PGRI Kediri.

Hashem, H. F. (2009). Adaptive technique for human face detection using HSV color space and neural networks. National Radio Science Conference. IEEE.

Haswan, F. (2015). Sistem Pendukung Keputusan Dalam Pemilihan Guru Teladan Pada SMPN 1 Teluk Kuantan. JURNAL SAINTIKOM UNIKS, 88-102.

Kusrini, K., \& Gole, A. W. (2007). Sistem Pendukung Keputusan Penentuan Prestasi Pegawai Nakertrans Sumba Barat di Waikabubak. Seminar Nasional Aplikasi Teknologi Informasi (SNATI), (pp. 47-52). Yogyakarta.

Kusuma, A., Nasution, A., Safarti, R., Hondro, R. K., \& Buulolo, E. (2018). Sistem Pendukung Keputusan Pemilihan Siswa/I Teladan Dengan Menggunakan Metode MultiObjective Optimization on The Basis of Ratio Analisis (MOORA). JURIKOM (Jurnal Riset Komputer), 114-119.

Kusumadewi, S., Hartati, S., Harjoko, A., \& Wardoyo, R. (2006). Fuzzy Multi-Attribute Decision
Making (Fuzzy MADM). Yogyakarta: Graha Ilmu.

Mufizar, T., Susanto, S., \& Nurjayanti, N. (2015). Sistem Pendukung Keputusan Penilaian Kinerja Guru di SDN Mohammad Toha Menggunakan Metode Analytical Hierarchy Process (AHP). Proceedings Konferensi Nasional Sistem dan Informatika (KNS\&I) (pp. 581-586). Bali: STMIK STIKOM Bali.

Permendiknas. (35 Tahun 2010). Petunjuk Teknis Pelaksanaan Jabatan Fungsional Guru Dan Angka Kreditrnya. Jakarta: Kementerian Pendidikan Indonesia.

Pittsburgh, U. o. (2019, February 18). University of Library System. Retrieved from Citation Styles: APA, MLA, Chicago, Turabian, IEEE: APA 6th Edition: https://pitt.libguides.com/c.php?g=12108\&p= 64730

Pressman, S. R. (2005). E-book Software Engineering: a Practitioner's Approach. Seventh Edition. McGraw-Hill Higher Education.

Rivai, V. (2004). Manajemen Sumber Daya Manusia untuk Perusahaan dari Teori ke Praktik. Jakarta: PT RajaGrafindo Persada.

Saaty, T. L. (2008). Decision making with the analytic hierarchy process. Pittsburgh: Katz Graduate School of Business.

Sallis, E. (2002). Total Quality Management in Education. 3rd Edition. United States of America: Stylus Publishing Inc.

Turban, E., Rainer, J., Kelly, R., \& Potter, R. E. (2006). Introduction to Information Systems: Supporting and Transforming Business. Wiley \& Sons, Incorporated, John. 